\title{
Customer Satisfaction at Tiki.vn E-Commerce Platform
}

\author{
Ha Nam Khanh GIAO*
}

Received: February 4, 2020 Revised: March 1, 2020 Accepted: March 6, 2020.

\begin{abstract}
This study has four objectives: (1) Identifying factors that affect customer satisfaction on online service quality of Tiki.vn, (2) Measuring the level of impact of the factors, (3) Testing the difference in satisfaction among groups of customers with different characteristics in terms of gender, age, income, academic level, and occupation, and (4) Proposing some managerial implications to improve the quality of online services by interviewing directly and online 200 individual customers who have shopped at Tiki.vn E-commerce platform for at least the last six months, using the convenient sampling method. This study analyzes the reliability of the scale through the Cronbach's alpha coefficient, Exploratory factor analysis, and Linear regression analysis. The findings identified four factors that influence positively customer satisfaction regarding the quality of online services in Tiki.vn E-commerce platform in the order of descending strength: (1) Trust, (2) Customer service, (3) Web design and (4) Safety. In addition, the results show no difference in customer satisfaction according to different academic levels, but in terms of occupation and income, gender, and age. The results show that the factors influencing most customer satisfaction are Reliability and Customer Service. Some managerial implications are then proposed to improve the quality of online shopping services at Tiki.vn.
\end{abstract}

Keywords: Online Shopping, Customer Satisfaction, Tiki, E-commerce Platform. Vietnam

JEL Classification Code: B16, M10, M31

\section{Introduction}

In Vietnam, the Internet is becoming pervasive and directly influences the consumption habits of a large part of Vietnamese people. The online shopping service has become popular and has been chosen by many people, especially the busy ones. The Vietnam E-Commerce and Information Technology Agency's (VECITA) Ministry of Industry and Trade reported that the proportion of Internet users participating in online shopping is $62 \%$. Estimates of the online shopping value of each individual is over 1 million VND/year, of which $32 \%$ of shoppers said they spent over 5 million VND for online purchases. Vietnam E-

*First Author and Corresponding Author. Dean, Faculty of Air Transport, Vietnam Aviation Academy, Vietnam [Postal Address: A65 Nam Thong 1 Town, Phu My Hung Zone, Tan Phu Ward, District 7, Ho Chi Minh City, 72908, Vietnam] Tel: +84 903306363, Email: khanhgiaohn@yahoo.com

(c) Copyright: The Author(s)

This is an Open Access article distributed under the terms of the Creative Commons Attribution Non-Commercial License (http://Creativecommons.org/licenses/by-nc/4.0/) which permits unrestricted noncommercial use, distribution, and reproduction in any medium, permits unrestricted noncommercial use,
provided the original work is properly cited. commerce Association (VECOM) announces that Vietnam e-commerce grows at the rate of around $25 \%$ continuously from 2017 up to 2020. This shows that Vietnam Ecommerce is considered as "golden land", "potential" and "extremely fertile".

Recently, scholars pay more attention on the e-commerce development, Kussusanti, Tjiptoherijanto, Halim, and Furinto (2019), and $\mathrm{He}$ and Wang (2019) published researches in the field of e-commerce service, but not on customer satisfaction, and not Vietnam-based. In Vietnam, however, concerns about poor product quality, weaknesses in freight forwarding, channels, lack of professionalism in online payment, lack of data confidentiality, buyers not having credit cards or a payment card, concerns over warranty, the seller not complying with commitments, etc., have caused a lot of difficulties for the E-commerce industry in general and Tiki Corporation, in particular (which is actually Tiki.vn), because it has not gained a high level of trust and satisfaction from consumers, leading to limitation of the scale and turnover not matching the potential. Therefore, the study of customer satisfaction on 
the quality of online services at Tiki.vn E-commerce platform is really necessary.

Tiki.vn is the E-commerce platform of Tiki Corporation connecting buyers and sellers nationwide. Tiki.vn launched its online English books selling in 2010, and open up to consumer products in 2013 when receiving Sumitomo's capital investment. The main mode of business of Tiki.vn is C2C. Through the departments opened on Tiki.vn, small and medium enterprises can provide products and services to the consumer. In 2017, Tiki became the only provider of a fast 2-hour TikiNOW delivery service in the region, the company is proud of its philosophy slogan, Tiki, which in Vietnamese means Tìm Kiếm (Exploring) \& Tiết Kiệm (Saving). Also told ir the story from Tiki's $100 \mathrm{~m} 2$ warehouse growing to a $2,000 \mathrm{~m} 2$ facility after receiving the first investment from Sumitomo Japan in 2013. By 2019, Tiki operates ten fulfillment centers in major cities with a total area of $60,000 \mathrm{~m} 2$ - a 30 -fold increase compared to 2013. Tiki has a warehouse system operating on a semiautomatic model, which will gradually increase to automation and hi-tech application. Tiki.vn nowdays ranks third in the Big Four E-commerce platform in Vietnam at the end of the third quarte of 2019, with 26.3 million visits (the first is Shopee.vn with 30.9 million visits and the second is sendo.vn with 27.1 million visits).

\section{Literature Review and Research Model}

\subsection{The Concepts}

\subsubsection{Service}

Service is a common concept in marketing and business. There are many ways to define services, according to Zeithaml and Bitner (2003), "Services are behaviors, processes, and ways of performing a task that create value for the customer to satisfy the needs and expectations of customers." Services are activities for which one party (the service providers) can provide for customers that are mostly invisible and does not transfer ownership (Kotler \& Amstrong, 2004). The service can be attached or not attached to a physical product. Thus, the service has the following basic characteristics to distinguish tangible products: Invisibility, Heterogeneity, Inseparability, Nonstorability.

According to Lehtinen and Lehtinen (1982), service quality must be evaluated in two respects as the process of service delivery and the outcome of the service. According to Parasuraman, Berry, and Zeithaml (1985) and Parasuraman, Zeithaml, and Berry (1988), the quality of service is defined as the distance between customers' expectations for service and their perception after using that service. Gronroos (2000) also suggested two areas of service quality that are technical quality and functional quality.

\subsubsection{Online Shopping Service}

According to Kotler and Amstrong (2004), online shopping is the purchase of electronic communications between buyers and sellers - usually online. Online shopping allows buyers to contact new suppliers, cut down on purchasing costs, and quickly process orders. At the same time, marketing professionals can connect online with customers to share marketing information, sell products and services, provide support services, and maintain existing relationships with customers. According to Bui (2014), online shopping is a process where customers purchase goods or services directly from a seller for a period of time through the internet, without intermediaries - a form of Ecommerce. Online shopping benefits both buyers and sellers in terms of customer search, product information, process interaction, and product distribution.

According to Santos (2003), the quality of online services is determined by the customer's overall judgment and evaluation of the service delivery process in a virtual market. The enterprise having had experience and success in providing online services usually begins with the statement that in addition to the presence of the site, low prices, the importance in the success or failure also includes quality online service elements. Customers using online services expect the quality of service provided to be equal to or above the quality of traditional services.

\subsubsection{Consumer Satisfaction}

There are many definitions of customer satisfaction. Satisfaction is the level of a person's sense that results from comparing the benefits obtained with the product to his or her expectations (Kotler \& Amstrong, 2004). Bachelet's (1995) definition of a customer satisfaction is an emotional reactions of customers responding with their experience with a product or service. According to Oliver (1997), satisfaction is the reaction of consumers towards the expectations being met. This definition implies that satisfaction is the satisfaction of the consumer in the consumption of the product or service that meets his or her desires, including the level of satisfaction above the desired level and below the desired level (Giao, 2018; Giao, Hoai, \& Vinh, 2019).

Many studies of customer satisfaction in the service sector conclude that service quality and satisfaction are two distinct concepts. In Oliver's view (1993), service quality affects the level of customer satisfaction. According to Cronin and Taylor (1994), quality of service leads to customer satisfaction. Spreng and Mackoy (1996) also point out that quality of service is a precondition for 
customer satisfaction, and the price factor also needs to be considered when researching customer satisfaction.

\subsection{Some Scale Models of Online Service Quality}

The application of E-commerce in enterprises is increasing, and businesses are aware of the importance of measuring and controlling the quality of online services. Accordingly, many studies develop and propose scales that are suitable for the context of the quality of online services.

Table 1: Quality scale of retail via EtailQ network

\begin{tabular}{|c|c|c|}
\hline Component & $\begin{array}{l}\text { Observed } \\
\text { variables }\end{array}$ & Content \\
\hline \multirow{3}{*}{ Reliability } & $\begin{array}{l}\text { Getting the right } \\
\text { order }\end{array}$ & $\begin{array}{l}\text { I received the exact item I } \\
\text { ordered from this site. }\end{array}$ \\
\hline & On time delivery & $\begin{array}{l}\text { Products are delivered on } \\
\text { quality referrals on the site. }\end{array}$ \\
\hline & $\begin{array}{l}\text { Delivering the right } \\
\text { quality }\end{array}$ & $\begin{array}{l}\text { Products are delivered on } \\
\text { quality referrals on the site. }\end{array}$ \\
\hline \multirow{5}{*}{ Web design } & $\begin{array}{l}\text { Providing full } \\
\text { information }\end{array}$ & $\begin{array}{l}\text { The website provides enough } \\
\text { information. }\end{array}$ \\
\hline & $\begin{array}{l}\text { Effective } \\
\text { processing }\end{array}$ & $\begin{array}{l}\text { The site does not take me much } \\
\text { time to trade. }\end{array}$ \\
\hline & Processing speed & $\begin{array}{l}\text { Quickly and easily complete a } \\
\text { web-based transaction }\end{array}$ \\
\hline & Personalized & $\begin{array}{l}\text { The level of personalization of } \\
\text { the site is appropriate }\end{array}$ \\
\hline & Product portfolio & $\begin{array}{l}\text { The site has a good product } \\
\text { catalog. }\end{array}$ \\
\hline \multirow{3}{*}{ Safety } & Personal privacy & $\begin{array}{l}\text { I feel that my personal } \\
\text { information is protected at this } \\
\text { site. }\end{array}$ \\
\hline & Safe feeling & $\begin{array}{l}\text { I feel safe making transactions } \\
\text { at this site. }\end{array}$ \\
\hline & Safety assurance & Full site security and privacy. \\
\hline \multirow{3}{*}{$\begin{array}{l}\text { Customer } \\
\text { service }\end{array}$} & Ready to respond & $\begin{array}{l}\text { The company is very willing to } \\
\text { respond to customer inquiries. }\end{array}$ \\
\hline & $\begin{array}{l}\text { Desire to fix } \\
\text { problems. }\end{array}$ & $\begin{array}{l}\text { When encountering a problem, } \\
\text { the website expresses the } \\
\text { interest in solving it. }\end{array}$ \\
\hline & Quick service & $\begin{array}{l}\text { Questions are answered } \\
\text { promptly. }\end{array}$ \\
\hline
\end{tabular}

(Source: Wolfinbarger \& Gilly, 2003)

The majority of models developed from the SERVQUAL model, especially the E-SQ model (Parasuraman, Zeithaml, $\&$ Malhotra, 2005), cover most of the scale components in the studies: (1) Reliability, (2) Responsiveness, (3) Access, (4) Flexibility, (5) Ease of Navigation, (6) Efficiency, (7) Assurances/Trust, (8) Security/Privacy, (9) Price Knowledge, (10) Site Aesthetics, and (11) Customization/Personalization. Parasuraman et al. (2005) analyzed the composition scales and separated the components into two independent models. The first model is the ES-qual model including four components: (1) Efficiency, (2) Fulillment, (3) System availability, and (4) Privacy. Model 2 is the E-ReS-qual model including three components: (1) Responsiveness, (2) Compensation, and (3) Contact.

In addition, there is a fairly general model of retail quality over the network, which is the EtailQ retail quality model published by Wolfinbarger and Gilly (2003). It consists of four main components (see Table 1).

After compiling and comparing, it can be seen that the EtailQ model of Wolfinbarger and Gilly (2003) contains all contents of E-SQ, ES Qual and E-ReS Qual models (see Table 2).

Table 2: EtailQ, ES Qual, E-ReS Qual

\begin{tabular}{|l|l|l|}
\hline \multicolumn{1}{|c|}{ EtailQ Model } & \multicolumn{1}{|c|}{ ES Qual Model } & E-ReS Qual Model \\
\hline Web design & $\begin{array}{l}\text { Efficiency } \\
\text { System availability }\end{array}$ & \\
\hline $\begin{array}{l}\text { Reliability / } \\
\text { Compliance with } \\
\text { Commitments }\end{array}$ & Fullfillment & \\
\hline Security / Privacy & Privacy & $\begin{array}{l}\text { Responsiveness } \\
\text { Compensation } \\
\text { Contact }\end{array}$ \\
\hline Customer service & & \\
\hline
\end{tabular}

\subsection{Research Models and Hypotheses}

Based on the synthesis and comparison of the E-SQ model, ES Qual and E-ReS Qual of Parasuraman et al. (2005) and EtailQ model of Wolfinbarger and Gilly (2003) (see Table 2), inheriting previous studies, the study model of Wolfinbarger and Gilly (2003) is used to implement this topic. Research hypotheses in this topic include (see Figure $1)$ :

$\mathbf{H}_{1}$ : The customers' perception of web design increases or decreases, depending on their increase or decrease level of satisfaction with online shopping.

$\mathbf{H}_{2}$ : The customers' perception of the level of trust in online shopping at the site increases or decreases, depending on their increase or decrease level of satisfaction with online shopping.

$\mathbf{H}_{3}$ : The customers' perception of the safety of online shopping at the site increases or decreases, depending on 
their increase or decrease level of satisfaction with online shopping.

$\mathbf{H}_{4}$ : The customers' perception of customer service of online shopping at the site increases or decreases, depending on their increase or decrease level of satisfaction with online shopping.

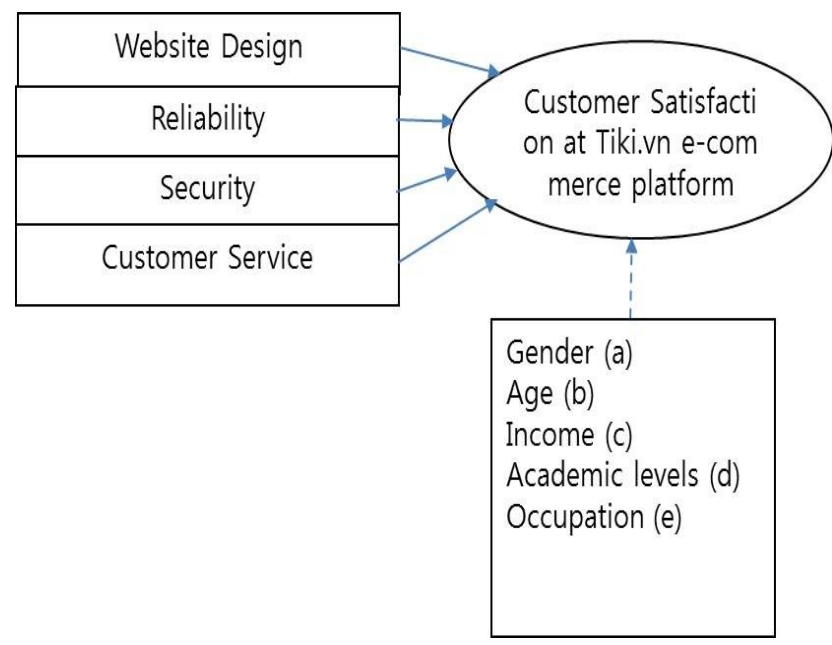

Figure 1: Recommended research model

The hypothesis of the impact of demographic variables on the relationship between quality of online services and customer satisfaction.

$\mathbf{H}_{5 \mathbf{a}}$ : There is a difference in satisfaction of the quality of shopping services by Gender.

$\mathbf{H}_{5 \mathbf{b}}$ : There is a difference in satisfaction of the quality of shopping services by Age.

$\mathbf{H}_{\mathbf{5}}$ : There is a difference in satisfaction of the quality of shopping services by Income.

$\mathbf{H}_{\mathbf{5} \mathbf{d}}$ : There is a difference in satisfaction of the quality of shopping services by Academic level.

$\mathbf{H}_{\mathbf{5}}$ : There is a difference in satisfaction of the quality of shopping services by Occupation.

\section{Results and Discussion}

\subsection{Sample Description Statistics}

After interviewing directly and online 250 individual customers having been shopping at Tiki.vn for at least the last six months using a convenient sampling method, 200 survey samples meeting the requirements were included in the official study. Statistics describe the sample as shown in Table 3 and Table 4.
Table 3: Official survey sample information

\begin{tabular}{|c|c|c|c|}
\hline & $\begin{array}{c}\text { Survey sample } \\
\text { information }\end{array}$ & Frequency & $\begin{array}{c}\text { Ratio } \\
(\%)\end{array}$ \\
\hline \multirow{2}{*}{ Gender } & Male & 100 & 50.0 \\
\hline & Female & 100 & 50.0 \\
\hline \multirow{3}{*}{ Age } & Under 18 & 19 & 9.5 \\
\hline & $18-24$ & 100 & 50.0 \\
\hline & $25-35$ & 81 & 40.5 \\
\hline \multirow{3}{*}{ Income } & Under 5 million & 21 & 10.5 \\
\hline & $\begin{array}{l}\text { Between } 5 \text { and } 10 \\
\text { million }\end{array}$ & 119 & 59.5 \\
\hline & Over 10 million & 60 & 30.0 \\
\hline \multirow{2}{*}{$\begin{array}{l}\text { Academic } \\
\text { level }\end{array}$} & Below University & 42 & 21.0 \\
\hline & $\begin{array}{c}\text { From University to } \\
\text { above }\end{array}$ & 158 & 79.0 \\
\hline \multirow{3}{*}{ Occupation } & Students & 19 & 9.5 \\
\hline & Employees & 120 & 60.0 \\
\hline & Managers & 61 & 30.5 \\
\hline
\end{tabular}

Table 4: Statistics of shopping habits

\begin{tabular}{|c|c|c|c|}
\hline & $\begin{array}{c}\text { Statistics of } \\
\text { shopping habits }\end{array}$ & Frequency & $\begin{array}{l}\text { Ratio } \\
\text { (\%) }\end{array}$ \\
\hline \multirow{4}{*}{$\begin{array}{l}\text { Level of } \\
\text { purchase }\end{array}$} & 1-2 times a month & 78 & 39.0 \\
\hline & 3-4 times a month & 44 & 22.0 \\
\hline & $\begin{array}{c}\text { More than } 4 \text { times a } \\
\text { month }\end{array}$ & 32 & 16.0 \\
\hline & $\begin{array}{l}\text { Rarely purchase } \\
\text { online }\end{array}$ & 46 & 23.0 \\
\hline \multirow{5}{*}{$\begin{array}{l}\text { Purchase } \\
\text { items }\end{array}$} & $\begin{array}{l}\text { Men/Women, } \\
\text { Mother and Baby } \\
\text { Fashion }\end{array}$ & 100 & 50.0 \\
\hline & $\begin{array}{l}\text { Technology, } \\
\text { electrical } \\
\text { appliances }\end{array}$ & 26 & 23.0 \\
\hline & Houseware & 22 & 11.0 \\
\hline & Food & 17 & 8.5 \\
\hline & Others & 15 & 7.5 \\
\hline \multirow{6}{*}{$\begin{array}{l}\text { The forms of } \\
\text { online } \\
\text { shopping }\end{array}$} & $\begin{array}{l}\text { Online sales } \\
\text { website }\end{array}$ & 43 & 21.5 \\
\hline & $\begin{array}{l}\text { Electronic trading } \\
\text { platform }\end{array}$ & 26 & 13.0 \\
\hline & $\begin{array}{l}\text { Group buying } \\
\text { website }\end{array}$ & 33 & 16.5 \\
\hline & $\begin{array}{l}\text { Forums, social } \\
\text { networks }\end{array}$ & 47 & 23.5 \\
\hline & $\begin{array}{l}\text { Online shopping } \\
\text { applications } \\
\text { installed on the } \\
\text { mobile }\end{array}$ & 25 & 12.5 \\
\hline & $\begin{array}{l}\text { Classifieds on news } \\
\text { sites }\end{array}$ & 26 & 13.0 \\
\hline
\end{tabular}




\subsection{Testing Scale Reliability}

After analyzing Cronbach's Alpha, the scales met the criteria (Cronbach's Alpha coefficient $\geq 0.6$ and correlation variable coefficient - total correction $\geq 0.3$ ) (see Table 5). Therefore, it is used to analyze the next EFA.

Table 5: Results of the reliability calculation of the scale

\begin{tabular}{|c|c|c|c|c|c|}
\hline No. & Scale & Symbol & $\begin{array}{c}\text { Number } \\
\text { of } \\
\text { observed } \\
\text { variables }\end{array}$ & $\begin{array}{c}\text { Cronbach's } \\
\text { Alpha }\end{array}$ & $\begin{array}{c}\text { Smallest } \\
\text { Item-Total } \\
\text { Correlation }\end{array}$ \\
\hline 01 & Web design & WD & 6 & 0.798 & .461 \\
\hline 02 & Reliability & REL & 5 & 0.873 & .511 \\
\hline 03 & Security & SE & 5 & 0.893 & .682 \\
\hline 04 & $\begin{array}{c}\text { Customer } \\
\text { service }\end{array}$ & CS & 4 & 0.770 & .643 \\
\hline 05 & Satisfaction & SAT & 4 & 0.879 & .704 \\
\hline
\end{tabular}

\subsection{Analyzing the EFA}

EFA for the independent variables shows the KMO coefficient $=0.766>0.5$ with $\mathrm{Sig}=0.000<0.05$, indicating that the observed variables belong to the same factor correlating closely. Also, the total extracted variance of $65,300 \%>50 \%$ shows that these four factors explain $65,300 \%$ the variation of the dataset and Eigenvalue = $2,532>1$ qualifying factor analysis (see Table 6).

Table 6: Results of EFA of service quality factors

\begin{tabular}{|c|c|c|c|c|}
\hline & \multicolumn{4}{|c|}{ Factor loading } \\
\cline { 2 - 5 } & $\mathbf{1}$ & $\mathbf{2}$ & $\mathbf{3}$ & $\mathbf{4}$ \\
\hline $\mathrm{SE}_{3}$ & 0.922 & & & \\
\hline $\mathrm{SE}_{4}$ & 0.906 & & & \\
\hline $\mathrm{SE}_{2}$ & 0.804 & & & \\
\hline $\mathrm{SE}_{1}$ & 0.799 & & & \\
\hline $\mathrm{SE}_{5}$ & 0.795 & & & \\
\hline $\mathrm{REL}_{5}$ & & 0.889 & & \\
\hline $\mathrm{REL}_{3}$ & & 0.849 & & \\
\hline
\end{tabular}

\begin{tabular}{|l|l|l|l|l|}
\hline $\mathrm{REL}_{2}$ & & 0.824 & & \\
\hline $\mathrm{REL}_{1}$ & & 0.817 & & \\
\hline $\mathrm{REL}_{4}$ & & 0.644 & & \\
\hline $\mathrm{WD}_{3}$ & & & 0.791 & \\
\hline $\mathrm{WD}_{1}$ & & & 0.709 & \\
\hline $\mathrm{WD}_{2}$ & & & 0.704 & \\
\hline $\mathrm{WD}_{6}$ & & & 0.696 & \\
\hline $\mathrm{WD}_{4}$ & & & 0.693 & \\
\hline $\mathrm{WD}_{5}$ & & & 0.612 & \\
\hline $\mathrm{CS}_{1}$ & & & & 0.933 \\
\hline $\mathrm{CS}_{4}$ & & & & 0.912 \\
\hline $\mathrm{CS}_{3}$ & & & & 0.810 \\
\hline $\mathrm{CS}_{2}$ & & & & 0.766 \\
\hline
\end{tabular}

EFA of the dependent variable group showed that $\mathrm{KMO}$ and Bartlett's in the analysis of factors have sig. $=0.000$ and $\mathrm{KMO}=0.801>0.5$; The Eigenvalue value is $2.942>1$. Therefore, the extracted scales are acceptable. All four observed variables have factor loadings which are greater than 0,5 . Thus the scale satisfies the convergence value and reliability (see Table 7).

Table 7: EFA results of the service quality satisfaction scale

\begin{tabular}{|c|c|}
\hline & Factor loading \\
\cline { 2 - 2 } & $\mathbf{1}$ \\
\hline SAT4 & 0.897 \\
\hline SAT3 & 0.861 \\
\hline SAT2 & 0.837 \\
\hline SAT1 & 0.834 \\
\hline
\end{tabular}

\subsection{Correlation Analysis}

Test of $\mathrm{r}$ correlation coefficient shows that results in Table 8 with meaning level of 0.01 (reliability 99\%) and 0.05 (reliability 95\%) of all four components of independent variable scale have a positive correlation to the quality of service, so they can be put into regression (see Table 8).

Table 8: Pearson correlation

\begin{tabular}{|c|c|c|c|c|c|c|}
\hline \multicolumn{2}{|c|}{} & WD & REL & SE & CS & SAT \\
\hline \multirow{2}{*}{ WD } & Pearson Correlation & 1 & -0.120 & 0.069 & $-0.165^{*}$ & $0.342^{* *}$ \\
\cline { 2 - 7 } & Sig. (2-tailed) & & 0.091 & 0.330 & 0.020 & 0.000 \\
\hline \multirow{2}{*}{ REL } & Pearson Correlation & -0.120 & 1 & -0.069 & $0.188^{* *}$ & $0.558^{* *}$ \\
\cline { 2 - 7 } & Sig. (2-tailed) & 0.091 & & 0.335 & 0.008 & 0.000 \\
\hline \multirow{2}{*}{ SE } & Pearson Correlation & 0.069 & -0.069 & 1 & 0.052 & $0.166^{*}$ \\
\cline { 2 - 8 } & Sig. (2-tailed) & 0.330 & 0.335 & & 0.465 & 0.019 \\
\hline
\end{tabular}




\begin{tabular}{|c|c|c|c|c|c|c|}
\hline \multirow{3}{*}{ CS } & Pearson Correlation & $-0.165^{*}$ & $0.188^{* *}$ & 0.052 & 1 & $0.366^{* *}$ \\
\cline { 2 - 7 } & Sig. (2-tailed) & 0.020 & 0.008 & 0.465 & 0.000 \\
\hline \multirow{2}{*}{ SAT } & Pearson Correlation & $0.342^{* *}$ & $0.558^{* *}$ & $0.166^{*}$ & $0.366^{* *}$ & 1 \\
\cline { 2 - 7 } & Sig. (2-tailed) & 0.000 & 0.000 & 0.019 & 0.000 & \\
\hline
\end{tabular}

\subsection{Regression Analysis}

Table 9 shows that the adjusted $\mathrm{R} 2$ is 0.605 , ie $60.5 \%$ the variation of SAT (explained by variation of four independent variables WD, REL, SE, CS. Durbin - Watson $\mathrm{d}=2.076(1<\mathrm{d}<3)$ showed no correlation between residuals. The sig. value of $\mathrm{F}(=77.337)$ has a very small sig. level $($ Sig. $=0.000<0.05)$, i.e. the linear regression model given is consistent with the collected data.

Table 9: Results of the regression analysis

\begin{tabular}{|c|c|c|c|c|c|c|c|c|}
\hline & \multirow{2}{*}{ Model } & \multicolumn{2}{|c|}{ Unstandardized coefficient } & \multirow{2}{*}{$\begin{array}{c}\begin{array}{c}\text { Standardized } \\
\text { coefficient }\end{array} \\
\text { Beta }\end{array}$} & \multirow{2}{*}{ Value $\mathbf{t}$} & \multirow{2}{*}{ Level of Significance } & \multicolumn{2}{|c|}{ Multicollinearity } \\
\hline & & B & Standard error & & & & Tolerance & VIF \\
\hline \multirow{5}{*}{1} & Constant & -0.231 & 0.332 & & -0.696 & 0.487 & & \\
\hline & WD & 0.259 & 0.026 & 0.453 & 9.957 & 0.000 & 0.960 & 1.042 \\
\hline & REL & 0.297 & 0.024 & 0.561 & 12.291 & 0.000 & 0.951 & 1.051 \\
\hline & SE & 0.246 & 0.071 & 0.156 & 3.477 & 0.001 & 0.986 & 1.014 \\
\hline & $\mathrm{CS}$ & 0.280 & 0.039 & 0.327 & 7.116 & 0.000 & 0.939 & 1.065 \\
\hline \multicolumn{9}{|c|}{$\begin{array}{l}\text { Adjusted } \mathrm{R}^{2}: 0.605 \\
\text { Durbin-Watson statistics: } 2.076 \\
\text { Statistics F (ANOVA): } 77.337 \\
\text { Level of Significance (Sig. of ANOVA): } 0.000\end{array}$} \\
\hline
\end{tabular}

The residual test showed that the residual distribution was approximately standard with Mean $=0$ and standard deviation $=0.990$ (approx. 1), so it can be concluded that the standard distribution hypothesis is not violated when using multiple regression.

On the other hand, in the visual image we see that the residuals of the model have a bell-shaped down-righted graph, so it is possible to conclude that the residuals of the model have a normal distribution. In addition, according to the P-P plot diagram, the observation points are not scattered too far from the expected line, so it can be concluded that the normal distribution of the residuals is not violated. According to the Scatterplot graph, the regression errors are distributed evenly on both sides of the average (zero errors) and do not follow a clear rule. This suggests that the error hypothesis of the constant regression model is appropriate. So, with the above results, we find that the regression model is consistent and statistically significant. We have the regression model as follows:

\section{$\mathrm{SAT}=-0.231+0.259 * \mathrm{WD}+0.297 * \mathrm{REL}+0.246 * \mathrm{SE}+$ $0.280 * \mathrm{CS}$}

We see that $\beta_{2}>\beta_{4}>\beta_{1}>\beta_{3}$ so that the factors that affect the overall satisfaction of service quality are in the descending order: REL $>\mathrm{CS}>\mathrm{WD}>\mathrm{SE}$.

\subsection{Difference Testing}

The purpose of this analysis is to find differences in the quality of service assessment by factors such as gender, age, academic level, income and occupation. In this section, ANOVA and T-test are used to find differences in characteristics of respondents versus the satisfaction of quality of service.

The results show that there is a difference in the quality of online shopping services by gender - women, especially are more satisfied with the quality of service at Tiki.vn than men. There is a difference in satisfaction with the quality of online shopping services by age. We found that, at the age of 18-24, service quality satisfaction was highest, followed by the 25-35 age group and the under 18 age group. There is a difference in the satisfaction of service quality by income. We found that at the salary of 5-10 million, the satisfaction of service quality was highest, followed by the income of less than 5 million with satisfaction of service quality ranked second. Earnings over 10 million have the lowest satisfaction of service quality.

There is no difference in the satisfaction of service quality by educational level. There is a difference in the satisfaction of service quality by occupation, in particular, we see the group of employees having the highest quality 
service satisfaction, followed by the two groups of managers and students with almost equal satisfaction of service quality.

\subsection{Testing the Hypotheses}

The results of testing hypotheses from correlation analysis, regression analysis, T-test and ANOVA analysis showed that the relationship between the independent variables of service quality satisfaction with the dependent variables and demographic characteristics is significant at 95\% confidence level (see Table 10).

Table 10: Results of hypothesis testing

\begin{tabular}{|c|c|c|c|}
\hline \multicolumn{2}{|c|}{$\begin{array}{c}\text { Group hypotheses of the impact of } \\
\text { service quality }\end{array}$} & $\begin{array}{l}\text { Regression } \\
\text { Coefficient }\end{array}$ & $\begin{array}{l}\text { Testing } \\
\text { result }\end{array}$ \\
\hline $\mathrm{H}_{1}$ & $\begin{array}{l}\text { Customers' perception of web site } \\
\text { design increases or decreases, } \\
\text { leading to the increase or decrease } \\
\text { in their level of satisfaction with } \\
\text { online shopping. }\end{array}$ & $\begin{array}{l}0,259 \\
(>0)\end{array}$ & Accepted \\
\hline $\mathrm{H}_{2}$ & $\begin{array}{l}\text { Customers' perception of the } \\
\text { reliability of online shopping } \\
\text { services at the site increases or } \\
\text { decreases, leading to the increase } \\
\text { or decrease in their level of } \\
\text { satisfaction with online shopping. }\end{array}$ & $\begin{array}{l}0,297 \\
(>0)\end{array}$ & Accepted \\
\hline $\mathrm{H}_{3}$ & $\begin{array}{l}\text { Customers' perception of the safety } \\
\text { of online shopping at the site } \\
\text { increases or decreases, leading to } \\
\text { the increase or decrease in their } \\
\text { level of satisfaction with online } \\
\text { shopping. }\end{array}$ & $\begin{array}{l}0,246 \\
(>0)\end{array}$ & Accepted \\
\hline $\mathrm{H}_{4}$ & $\begin{array}{l}\text { Customers' perception of customer } \\
\text { service of online shopping at the } \\
\text { site increases or decreases, leading } \\
\text { to the increase or decrease in their } \\
\text { level of satisfaction with online } \\
\text { shopping. }\end{array}$ & $\begin{array}{l}0,280 \\
(>0)\end{array}$ & Accepted \\
\hline \multicolumn{2}{|r|}{$\begin{array}{c}\text { Group hypotheses of the impact of } \\
\text { demographic variables }\end{array}$} & Sig & $\begin{array}{l}\text { Testing } \\
\text { result }\end{array}$ \\
\hline $\mathrm{H}_{5 \mathrm{a}}$ & $\begin{array}{l}\text { There is a difference in the } \\
\text { satisfaction of online shopping } \\
\text { service quality by gender }\end{array}$ & $\begin{array}{l}0,000 \\
<0,05\end{array}$ & Accepted \\
\hline $\mathrm{H}_{5 \mathrm{~b}}$ & $\begin{array}{l}\text { There is a difference in the } \\
\text { satisfaction of online shopping } \\
\text { service quality by age }\end{array}$ & $\begin{array}{l}0,000 \\
<0,05\end{array}$ & Accepted \\
\hline $\mathrm{H}_{5 \mathrm{c}}$ & $\begin{array}{l}\text { There is a difference in the } \\
\text { satisfaction of online shopping } \\
\text { service quality by income }\end{array}$ & $\begin{array}{l}0,000 \\
<0,05\end{array}$ & Accepted \\
\hline $\mathrm{H}_{5 \mathrm{~d}}$ & $\begin{array}{l}\text { There is a difference in the } \\
\text { satisfaction of online shopping } \\
\text { service quality by academic level }\end{array}$ & $\begin{array}{c}0,062 \\
>0,05\end{array}$ & Rejected \\
\hline $\mathrm{H}_{5 \mathrm{e}}$ & $\begin{array}{l}\text { There is a difference in the } \\
\text { satisfaction of online shopping } \\
\text { service quality by occupation }\end{array}$ & $\begin{array}{l}0,000 \\
<0,05\end{array}$ & Accepted \\
\hline
\end{tabular}

\subsection{Discussion}

The topic of this study is to explore the quality of online services that impact customer satisfaction at Tiki.vn. The results show that the factors influencing most customer satisfaction are Reliability and Customer Service, while Web Design and Security factors are less influential. In comparison with the results of Wolfinbarger and Gilly (2003), the factors of Reliability and Security give similar results, while Web Design and Customer Service are different.

Reliability has a positive impact on the satisfaction of online shoppers at Tiki.vn. This is consistent with previous research by Wolfinbarger and Gilly (2003). This impact shows that customer satisfaction is closely related to the reliability of Tiki.vn. Since Tiki.vn is an E-commerce platform, choosing a reputable, secure seller or shipping provider will be able to improve this position. In addition, the product should also have a provision of information to help customers be able to know and be more confident when shopping.

Customer service also has a positive impact on the satisfaction of online shoppers at Tiki.vn. This result is different from that of Wolfinbarger and Gilly (2003), but it is the same with the study of Giao and Tan (2014). This shows that customers are very interested in Tiki.vn customer service. In fact, the transaction between seller and buyer is completely natural without any intervention from Tiki.vn (C2C). As a result, the complaints and exchanges of goods, and compensation also took place more often. The responsibility of the business is to ensure the rights of the buyer and the seller do not suffer from any disadvantage, thereby enhancing the satisfaction of customers.

In the study by Wolfinbarger and Gilly (2003), Web design is one of the major contributors to customer satisfaction, but in this study it is only in the middle of the scale, which is similar to results of Lee and Lin (2005). This shows that customers are also interested in the requirements of the web design as beautiful, simple, easy to understand, and easy to manipulate, but that is not the key factor to satisfy the customer when shopping at Tiki.vn. The essence is that, after a long time in operation, the marketing and technical team of Tiki.vn has done a lot of testing and research on customer behavior to produce today's web version. Because this factor almost fulfills the requirements of customers, therefore for Tiki.vn, customers demand more activities after the promotion.

Surprisingly, the Security factor has the least impact on customer satisfaction when shopping at Tiki.vn. This result coincides with the original study by Wolfinbarger and Gilly (2003). This means that Safety does not have the positive effect on the satisfaction of online shoppers at Tiki.vn. In 
fact, customers are very concerned about the security of their accounts as it pertains to financial information being revealed when performing transactions on electronic shopping sites. However, Tiki.vn, a reputable service provider in the Vietnamese market, has somewhat reduced the concerns. At the same time, Tiki.vn also allows customers to make transactions without having to $\log$ in, or create accounts. Therefore, if having any concern, the customer can use this feature.

\section{Recommendations and Conclusion}

\subsection{Managerial Implications}

\subsubsection{Reliability}

The observed variables are quite good, with three variables $\mathrm{REL}_{2}, \mathrm{REL}_{3}$ and $\mathrm{REL}_{5}$ being above neutralization levels, but not reaching the agreed level.

REL $_{5}$ (Tiki.vn has always been committed to online promotions) is rated lowest in five observed variables of component Reliability, proving that customers have very negative attitudes with online promotions at Tiki.vn. This also leaves Tiki.vn executives with a headache as ever more sellers exaggerate the original price of the product, create a "virtual" promotion, state the product is out of stock, but without any warning, the quality is not the same as the description, etc., they makes customers less trusting in the program as well as the business. Of course, Tiki.vn is still trying to find a way to solve this factor to build trust with the customers.

$\mathrm{REL}_{3}$ (Tiki.vn has a clear refund policy) is a factor to be underestimated too. This shows that delivery as well as product return did not meet the requirements of customers. Tiki.vn has a policy of reimbursing shops who sell, but direct implementation occurs between the seller and the buyer, not through Tiki.vn, so it may lead to a bad situation due to shops not cooperating. In addition, some loyal customers still cannot identify Tiki.vn as a E-commerce platform, they think Tiki.vn is a shop. So, all questionable activities from the seller are attributed to Tiki.vn.

$\mathrm{REL}_{2}$ (I receive the right goods right at the first time (quantity, type , ... )) is the next factor with which customers less agree. Tiki.vn needs to work more closely with the seller to gradually improve this factor, making customers more satisfied with the quality of their online service.

Some of the suggestions below are intended to improve the reliability of the customer, thus increasing the level of customer satisfaction: Tiki.vn's commitments to online services and promotions must always be implemented in a timely and transparent manner, in terms of execution time, content and results. The promotion will have a team closely reviewing information and binding conditions to avoid the seller hiking up the original price and then suspending the price of $50-70 \%$. In addition, Tiki.vn may implement a mechanism through which a buyer can give a feedback on the seller who, after confirming the behavior, will be downgraded, affecting rank order and product appearance on the system. Tiki.vn should impose stringent penalties for sellers who do not comply with the set policy. If the customer gives bad feedback or points out violation, the seller's product will be taken down immediately. At the same time, Tiki.vn also has a program to protect the interests of customers, promptly send complaints within 48 hours from the receipt.

After collecting, reviewing and listening to all relevant evidence provided, the customer may receive a $100 \%$ refund of the value of the product, for example, in the event of a misrepresentation of the seller or delivery. Website systems need to be more clearly designed, especially the product category selection, to consistently fulfill customer requirements and orders. In addition, to avoid the product being out of stock, the seller should send the same product to the buyer without consulting. Tiki.vn encourages customers to check the product as soon as received. If the product is not the right one the customer orders, they have the right not to accept it and the seller will have to pay the return fee.

\subsubsection{Customer Service}

In general, all variables are in the range of 4.2 to 4.4 , with $\mathrm{KH}_{2}$ variable. "Staff of Tiki.vn clearly consult, instruct and assist me in times of transactional problems" is rated the lowest. Consequently, it is necessary to maintain and further improve Customer Service to enhance customer satisfaction when shopping online at Tiki.vn. Some suggestions for the Customer Service factor are as follows:

Rapid response speed, immediate response to customer inquiries, complaints and continuous customer care are the keys to bring satisfaction and trust to customers. As a result, Tiki.vn needs to improve its information retrieval process and handling of complaints, ensuring that the steps of receiving applications, handling complaints, and reporting results to customers must be within the maximum allowable time frame, while ensuring this process is strictly adhered. Customers must always be up-to-date on how their inquiries are being addressed and when the results are processed.

In addition to the information provided on the current site, it is advisable to add robotic chats and display them in an eye-catching location on the site to better serve customers, ensuring that the customers are always connected to the customer care department of Tiki.vn when they need it. Add the "Call Customer Care" section on the application so that customers can use the phone at any time. Routine 
training courses on customer service, negotiation skills, communication skills, problem solving skills, etc are needed. Regularly update staff knowledge to better advise and instruct customers, limiting professional errors to annoy customers. Strengthen the human resources of customer care through hotline, email, especially when the transaction occurred.

\subsubsection{Web Design}

The difference in customer ratings between observed variables is not high. This component does not impact customer satisfaction when shopping online at Tiki.vn, but it still has the most impact. Web design makes the first impression in the hearts of customers when first visiting the site. Therefore, Tiki.vn must pay attention to this factor to increase the satisfaction of customers with the quality of online service at Tiki.vn.

Some suggestions for improving Web Design are as follows: In terms of website design, the eye-catching website interface will create a good first impression for the customer. Therefore, Tiki.vn needs to re-evaluate the aesthetics and features of the site. Refer to the website design of competitors to capture the advantages. In addition, periodic A/B Testing should be used to capture the tastes of the users, improve the interface to catch the eye and help customers feel excited, not bored in the process of doing transactions. However, make sure the site design is simple, compact, not too complicated, or picky. Simplify the customer experience while performing transactions, reducing clicks to the minimum possible to complete a transaction. Websites need to have modeling steps or clear instructions so that customers easily understand the procedures and can easily finish.

Website structure should be clear, easy to find and manipulate, avoid making guests spend too much time to search for information or learn procedures, and explain how to trade through the site. Upgrade the server system, the fiber optic cable, and regularly inspect and maintain it to ensure good transmission lines, optimizing the speed of access to the site. Ensure that the information is provided accurately, adequately, completely, in a timely manner so customers always have the latest updates and find the information they need. Have clear regulations to the seller about posting valid information, product images and a censorship department to check the information before posting.

\subsubsection{Security}

Customers' assessment of the safety of Tiki.vn is not high. Customer ratings for this factor are significantly lower than the previous three factors, which were approximately 1.9 to 3.5 , indicating that customers are not satisfied with the safety of Tiki.vn.
Some suggestions for the Safety are as follows: Enhance the security of personal information and financial data. Apply modern security technologies, encryption techniques, new generation firewall application, access control system, etc., to prevent hackers from infiltrating the system to steal personal data, and client accounts' financial information. Regularly check the security of the system by means of risk assessment and multiple attack. Ensure that transactions are always done correctly, especially online payments. If the transaction is not successful, refund should be made as quickly as possible, otherwise the customer will feel that the transaction is not secure and will not want to return to the online service. To do this, the Senpay system needs to be better and more automated, instead of having to manually filter each order.

The privacy policy, protection of personal information and transaction information of Tiki.vn must be clearly stated, specifying the rights and limits of Tiki.vn's liability for confidentiality. Tiki.vn needs to ensure that all customers who carry out transactions must read and understand the privacy policy of Tiki.vn. Tiki.vn needs to facilitate customer transactions without having to $\log$ in or register an account. Some customers are satisfied with this method because it is less likely to provide the most personal information, but this method also has many limitations. Regularly remind, check the professional ethics of employees to ensure that there will be no leak of customer information. Regularly maintain relationships with customers is also a means of strengthening cross-checking, detecting signs of insecurity of the system to take timely measures. Set up system to send notice on the website and email to customer to varify transactions and order status, payment status to bring customers peace of mind. Continue to maintain, enhance prestige and build image, brand of a leading e-commerce site in Vietnam today. This job requires a great deal of finance, human resources and time. However, what is earned in return is the trust of customers and peace of mind when using the online service provided by Tiki.vn.

\subsubsection{Demographic}

According to the research results, there is a difference in the satisfaction of shopping at Tiki.vn depending on the gender, age, income and occupation of customers. Specifically, female customers aged between 18 and 24 will love and be more satisfied when shopping at Tiki.vn. In addition, customers who mainly come to Tiki.vn are employees or managers in an income bracket of 5-10 million.

Some suggestions for demographic factor: Focus on developing Tiki.vn application to make it stronger and smoother, and to meet market trends and recognizing young customers love using mobile phones. Continue to maintain 
the strength of Tiki.vn, which is the product group in the low price segment. However, some of the products on the site now do not have the attributes that help filter the lowpriced products such as "under 1 million", "from 1 to 2 million" for example. so it will be very helpful for customers to find the right product for their income. Invest in promotions for female clients from 18 to 24 as this is the largest customer list in Tiki.vn now so as to easily achieve success as well as increase satisfaction of old customers. Establish a quality control department to eliminate counterfeit goods, fake goods, inferior quality goods, especially high value products, in order to increase the trust of customers with income of 10 million and above.

Implement internal promotions, enhance the shopping experience at Tiki.vn, leverage word of mouth to make more and more customers know about it. Combine banks to implement accompanying promotions, meeting the shopping needs of customers with medium and sufficient income. Select suitable advertising channels, social media for target customers from 18 to 24 years as such as OTT Chat channels, social networks.

\subsection{Conclusion}

This study was conducted with the objective of identifying and measuring the impact of online quality of service factors on customer satisfaction at Tiki.vn. The research was conducted through combining qualitative and quantitative methods with a valid sample size of 200 . Scales were verified by Cronbach's alpha reliability analysis, EFA, Pearson correlation analysis, multiple regression analysis, and the impact test of demographic variables..

As a result of the study, the most influential factors on customer satisfaction is Reliability, the second most influential factor is Customer Service, followed by Web Design and Security. The results show that all demographic variables, including Gender, Age, Income, and Occupation are different for customer satisfaction at Tiki.vn, except for Academic level.

\subsection{Limitations of the Research}

Limitations of the study are as follows: (1) The study was conducted only with customers who have shopped online at Tiki.vn, so its representativeness is not high, it is difficult to generalize the findings to other E-commerce websites; (2) The objective was to study only those consumers who have used the online service of Tiki.vn, so there will be limitations in offering solutions to improve the quality of online services without comparison with the service provided by other E-commerce sites; (3) The convenient sampling method was used, so the representativeness is not high; (4) The results only explain $60.5 \%$ of the variable value of the online service quality at Tiki.vn. This proves that there are other factors that affect the quality of service delivered by Tiki.vn this study has not mentioned. These limitations call for further research directions.

\section{References}

Bachelet, D. (1995). Measuring Satisfaction; or the chain, the tree and the nest. In R. Brookes (Ed.), Customer Satisfaction Research. Amsterdam, Netherlands: ESOMAR.

Bui, H. Y. G. (2014). Task readiness: Theoretical framework and empirical evidence from topic Familiarity, strategic Planning, and proficiency levels. In P. Skehan (Ed.), Processing Perspectives on Task Performance (pp. 63-94). Amsterdam, Netherlands: John Benjamins.

Cronin, J. J., \& Taylor, S. A. (1994). SERVPERF versus SERVQUAL: Reconciling Performance-Based and Perceptions-Minus-Expectations Measurement of Service Quality. Journal of Marketing, 58(January), 125-131.

Giao, H. N. K. (2018). Measuring Service Quality in Vietnamfrom the Customers Angle. Hanoi, Vietnam: Finance Publishing. DOI: 10.31219/osf.io/cqh68.

Giao, H. N. K., \& Tan, H. H. (2014). The Satisfaction of Customers on the groupon website Hotdeal.vn. Journal of Sciences of the University of Dong Thap, 8(April), 3-15. DOI: 10.31219/osf.io/dg36u.

Giao, H. N. K., Hoai, A. T., \& Vinh, P. Q. (2019). Management of Services Business- From the Angle of Marketing. Hanoi, Vietnam: Communication - Information Publishing. DOI: 10.31219/osf.io/98hrd.

Gronroos, C. (2000). Service Management and Marketing: a Customer Relationship Management Approach ( $2^{\text {nd }}$ ed). Chichester, England: John Wiley \& Sons, Ltd.

He, Y., \& Wang, J. (2019). A Panel Analysis on the Cross Border E-commerce Trade: Evidence from ASEAN Countries. Journal of Asian Finance, Economics and Business, 6(2), 95104. https://doi.org/10.13106/jafeb.2019.vol6.no2.95.

Kotler, P., \& Armstrong, G. (2004). Principles of Marketing. Upper Saddle River, NJ: Prentice Hall.

Kussusanti, S., Tjiptoherijanto, P., Halim, R. E., \& Furinto, A. (2019). Informational Justice and Post-recovery Satisfaction in E-Commerce: The Role of Service Failure Severity on Behavioral Intentions. Journal of Asian Finance, Economics and Business, 6(1), 129-139. http://doi.org/10.13106/jafeb.2019.vol6.no1.129.

Lee, G. G., \& Lin, H. F. (2005), Customer perceptions of e-service quality in online shopping. International Journal of Retail \& Distribution Management, 33(2), 161-176.

Lehtinen, J. R., \& Lehtinen, U. (1982). Service quality: a study of quality dimensions (Unpublished Working Paper). Service Management Institute, Helsinki, Finland.

Oliver, R. L. (1993). Cognitive, Affective, and Attribute Bases of the Satisfaction Response. Journal of Consumer Research, 20(3), 418-430.

Oliver, R. L. (1997). Satisfaction A Behavioral Perspective of the Consumer. New York, NY: McGraw-Hill.

Parasuraman, A., Berry, L. L., \& Zeithaml, V. A. (1985). A 
conceptual model of service quality and its implications for future research. Journal of Marketing, 49(4), 41-50. https://doi.org/10.1177/002224298504900403.

Parasuraman, A., Zeithaml, V. A, \& Berry, L. L. (1988). SERVQUALl: A Multiple-Item Scale for Measuring Consumer Perceptions of Service Quality. Journal of Retailing, 64(1), 1240.

Parasuraman, A., Zeithaml, V. A., \& Malhotra, A. (2005). E-S QUAL: Multiple-Item Scale for Assessing Electronic Service Quality. Journal of Service Research, 7(3), 213-234.

Santos, J. (2003). E-service quality: a model of virtual service quality dimensions. Management Service Quality, 13(3), 233246.

Spreng, R. A., \& Mackoy, R. D. (1996). An empirical examination of a model of perceived service quality and satisfaction. Journal of Retailing, 72(2), 201-214. https://doi.org/10.1016/S0022-4359(96)90014-7.

Wolfinbarger, M., \& Gilly, M. C. (2003). EtailQ: Dimensionalizing, Measuring and Predicting etail Quality. Journal of Retailing, 79(3), 183-198.

Zeithaml, V., \& Bitner, M. (2003). Services Marketing. New York, NY: McGraw-Hill. 